\title{
State's Authority Concerning Health Protection in Ordinary Times and During Epidemics
}

\author{
Władza państwa w zakresie ochrony zdrowia w czasie zwykłym i podczas epidemii
}

\author{
Jacek Meller \\ Institute of Philosophy, Cardinal Stefan Wyszyński University in Warsaw, Poland \\ ORCID https://orcid.org/0000-0002-0468-0168•j.meller@uksw.edu.pl \\ Received: 13 Sep, 2021; Revised: 27 0ct, 2021; Accepted: 5 Nov, 2021
}

\begin{abstract}
Life and health as fundamental matters are major concerns for every human being. To this end, he / she should be assisted by the community in which they live. If the foundation of social life is the personalistic principle, the recognition of the primacy of the dignity of the person, among other values, is constructed on the principles of subsidiarity and solidarity. It is the role of the healthcare institution to create such conditions, in which the safest and the most effective methods of treatment and prevention are available, and the individual can consciously select which of these realises his or her good to the greatest extent, in accordance with the recognised hierarchy of values, the accepted worldview, and life goals. The aim of this article is to analyse the relationship between the community and the individual, in the field of healthcare, under normal conditions and during epidemics. The existence of specific threats may suggest that exceptions to the fundamental rules of social life: autonomy, subsidiarity, and social solidarity, are permissible. However, the recognition of the fundamental value of the dignity of the person, requires the community to apply the same rules as in normal times, although many activities of public institutions are intensified in times of more serious danger.
\end{abstract}

Keywords: personal autonomy, epidemics, health protection, healthcare, social rules

Streszczenie: Życie i zdrowie jako dobra fundamentalne są ważnym przedmiotem troski każdego człowieka. Powinien on cieszyć się w tym pomocą ze strony społeczności, w której żyje. Jeśli fundamentem życia społecznego jest zasada personalistyczna, uznanie pierwszeństwa godności osoby wśród innych wartości, budowane jest ono według reguł pomocniczości i solidarności. Zadaniem instytucji ochrony zdrowia jest stworzenie takich warunków, w których dostępne będą możliwie bezpieczne i skuteczne metody terapii i prewencji, a jednostka w sposób świadomy będzie mogła wybrać to, co w największym stopniu realizuje jej dobro, w zgodzie z uznaną przez siebie hierarchią wartości, przyjętym światopoglądem i życiowymi celami.Celem artykułu jest analiza relacji między społecznością i jednostką w dziedzinie ochrony zdrowia w stanie normalnym i podczas epidemii. Istnienie szczególnych zagrożeń może sugerować, że dopuszczalne są wyjątki od stosowania fundamentalnych reguł życia społecznego: autonomii, pomocniczości i solidarności społecznej. Uznanie jednak podstawowej wartości, jaką jest godność osoby, nakazuje stosowanie przez społeczność tych samych reguł, co w czasie zwykłym, jakkolwiek wiele działań instytucji publicznych jest w czasie większego zagrożenia intensyfikowanych.

Słowa kluczowe: autonomia osoby, epidemia, ochrona zdrowia, zasady społeczne 


\section{Introduction}

The modern Western culture is, to a large extent, based on the idea of individual freedom, and the related subjective rights that significantly limit the interference of the community, represented by the state, in various spheres of human life. Individuals and groups of individuals are reluctant to surrender their autonomy; it can be taken away by deception, some benefits can be offered in exchange for its restriction, or it can be demonstrated that its maintenance will bring about some serious threat to the individual, or to the community as a whole. Such a threat may be, for example, terrorist attacks, but also a reduction of living standards, or quality of public services, due to the arrival in a country of many migrants, unprepared to live and work in a new environment. The aim of the article is to present the issue of the authority that the state has over its citizens, in the field of health protection in ordinary times, and when there's a particular threat to the life and health of many people, such as in an epidemic. If there is no danger of a mass contracting of a disease, a range of powers of social institutions is recognised, the purpose of which, is to ensure safety in this area; it is, therefore, expected that they will be intensified during an epidemic. However, the question must be asked regarding the extent of this extension, and its moral limits.

\section{Health and life are the object of special protection}

The value of human life and health finds its rationale in the recognition of the place of the body in the structure of the person, and of its role in that person's actions. Man does not so much "have" a body in the sense of possessing it, in the manner of various objects, but through it, he/she expresses himself/herself, acts, or communicates with others. The life of the body and its good condition, are thus, necessary for the creation of other goods, including immaterial, cultural goods, and for benefitting from them. Hence, although they are not the highest goods, they are of fundamental importance for man, and should be subject to special protection. The first person obliged to take care of his own body, is man himself. This obligation arises from the fact that, through the lifestyle he/she adopts, the diet he/ she follows, the hygiene he/she maintains, the exercise he/she does, and the stimulants he/she uses, all have a fundamental impact on the condition of his/her health. Therefore, in everyday life, he/she should choose what is conducive to staying healthy. This is a moral obligation, it is undertaken freely, and should be related to the broader context of life and fundamental choices. This freedom may be limited by the conditions of one's residence, the state of the local environment, or other circumstances beyond the control of the subject. A person can also make decisions on their own that are contrary to caring for his/her health, by choosing work that is necessary for the community, but dangerous, or by arranging their diet, according to the dictates of their religion (Brown 2013, Kluz 2016, 56-58; Wikler 2002).

Caring for life and health includes, apart from the choice of an appropriate lifestyle, the use of preventive and therapeutic measures offered by medicine. Also, in this sphere, one enjoys freedom, being free not to take any measures, or to choose the most appropriate ones from those available. Without going into the history of terminological disputes, we can say that this choice is made on two levels. The objective level relates to state-of-the-art medical knowledge and the advancement of techniques; we can discuss here, the proportionate and disproportionate therapeutic measures. The assessment of proportionality is based on recognition of the availability of therapeutic means, and their suitability for the situation of the individual patient, the risks to health and life, and the likelihood of adverse side effects, the existence and possibility of an alternative procedure, and finally, the distribution of the means considered within the care system. Medical developments 
mean that specific therapies, previously considered disproportionate because, for example, the number of devices needed to carry them out was too small, are now considered proportionate, following gradual improvements in the equipment of hospitals. On the other hand, the discovery of hitherto unknown risks of adverse side effects, may render a particular therapy disproportionate. The assessment of proportionality is carried out by the therapeutic team; it is based on the diagnosis previously made, and the recognition of the suitability of the means to achieve the intended medical goal; its result is presented to the patient (Ferdynus 2021, 73-74).

The patient, in turn, makes his/her own assessment of the therapeutic options presented to him/her, taking into account his/ her hierarchy of values, the order of his/her life goals, or the possibility of fulfilling his/ her commitments. He/She assesses the conventionality or exceptionality of a medical measure, on the basis of the anticipated effort involved in obtaining and using it, the possible unrelieved pain, the costs, his/her own fears or aversions regarding the proposed treatment, and the anticipated efficiency in relation to his/her own expectations, as well as conformity with his/ her moral or religious convictions. This is a subjective assessment: one patient may take the risk of an experimental therapy, with a not fully known efficiency and side effects, another - exhausted by previous procedures - may not agree to undertake another attempt, even if this one does not involve any serious risk (Ferdynus 2021, 74-75; Wróbel 1999, 412-414).

With the appropriate knowledge, having the support of people he/she trusts, each patient makes decisions about the treatment itself, and the selection of the necessary means, in the context of his/her moral views, religious faith, accepted goals. These measures must be proportionate (the use of disproportionate measures is medically impractical); if they are also ordinary, one can speak of a moral obligation to use them for the sake of the value of health and life; if they are extraordinary, one can accept them or refuse them.

Freedom in the sphere of health protection entails a twofold responsibility: for oneself and for the preservation of goods fundamental to one's existence and development, but also for others. Man is a social being, and lives in numerous relationships with others. One person's health condition influences both the shape of relationships with others, and the goods belonging to them. Therefore, choices made in this area should also take into account the preservation of these goods. In the context of these considerations, from the wide spectrum covering family relations, the sphere of economy, or various involvement in social life, the issues directly related to healthcare, should be highlighted. The nature of some diseases means that the pathogenic agent (virus, bacteria, fungus, parasite) may be transmitted from person to person, resulting in the deterioration of the health of many people. Hence, the illness of some, may directly contribute to the illness of others, also in large numbers.

Considering the possibility of the rapid spread of disease and the threat to the life and health of many, the protection of these goods can be referred to (with certain reservations) as the "common good", as it aims to create conditions, in which everyone will be able to preserve the values fundamental to them and pursue the goals they have adopted. Thus, state intervention is justified in order to preserve and promote the common good (Bartkowiak 2014; Marton-Gadoś 2014, 49). The community, therefore, pursues the objectives indicated in the international documents on the fundamental rights of persons. Admittedly, the phrase "right to health" does not appear in these texts this term would be debatable for many reasons - but other goods directly related to health are mentioned (Galewicz 2014; Tabaszewski 2016).

The state's actions, in the field of healthcare directly affecting citizens is twofold. On the one hand, through state institutions or 
supporting local government and private enterprise undertakings, the state ensures access to medical services. Their scope includes preventive measures (screening tests, vaccinations), treatment (outpatient and inpatient, provision of medicines and medical equipment) and rehabilitation. The state also has the task of creating rules for financing these services, whether from public funds (from taxes or social insurance), or through a system of private health insurance. Public financing of medical services has a more solidarity-based character: the level of services provided does not depend on the amount of tax or contribution paid, and people who are not payers towards the system, also receive life-saving aid. The other side of the state's activity is the imposition of obligations and restrictions on citizens. These may concern health protection directly, such as the obligation to undergo periodic examinations, or the compulsory treatment of certain diseases; or indirectly, such as regulations related to food marketing or work, and traffic safety (Kowalewski and Kowalewska 2014, 250-253; Łuczka 2006, 317; Jurkowska and Owsiak 2010, 117-188; Talone 2008).

The cooperation of individuals and social institutions created by them, should provide everyone with the conditions for preserving health and life, and in a threatening situation - for saving them. The problem that arises in building this cooperation, is to separate the competences of individuals and institutions, to indicate the limits of permissible state interference in the life of citizens.

\section{Relations between the individual and the state in the sphere of healthcare}

While considering the issue of the limits of state activity in the sphere of healthcare, the relationship between freedom and responsibility is worth noting, on the part of both communities and citizens. The wider the scope of action of the public institutions, the more competences they are granted, the greater their responsibility. Similarly, if they are deprived of their powers, leaving more matters to be decided by individuals, the less accountable they will be for the condition of healthcare. The question to consider is whether this is also the case in times of relative community health security, and a state of emergency, such as an epidemic.

\subsection{Limits of state intervention in ordinary times}

As a starting point, two extreme models can be presented, according to which, the relations between the state and the citizen may be arranged, also in the sphere of healthcare. The libertarian model, recognising the fundamental value of individual freedom and equal opportunities in access to various goods, postulates the minimisation of state interference in all spheres of citizens' lives, including health protection. This sphere is left to the free choices of individuals: both personal ones, concerning a particular lifestyle, choice of place for living, and type of work, undertaking preventive or therapeutic measures, as well as group ones, connected, for example, with the establishment of healthcare facilities or insurance institutions at the level of communes. The field of health services is here left to the operation of market laws, the task of state interference is to ensure the freedom and equality of action of those entities operating in this market. Some minor differences can be observed among libertarian concepts, related to the understanding of "minimal interference", to ensure basic security: whether it is to be only the prosecution of those who violate the fundamental rights of individuals or, for example, the formation of standards applicable to all entities. (Juzaszek 2014; Lewandowski 2013, 219; Nieszporska 2014, 82; O'Hara 2013).

In the collectivist model, the individual is not understood as a free individual who, having the necessary means at his/her disposal, takes care of various needs on his/her own initiative. The individual is necessarily a part of a community, whose welfare is subordinated to the actions of all its members. Therefore, the state is an entity, which sets the objectives to be attained and chooses 
the path to be followed. It is the state that organises the life of its citizens by taking responsibility for many of its elements, but at the same time, it restricts the freedom of individuals and suppresses their initiatives. In the area of healthcare, this is achieved through the creation of a public, compulsory, and often monopolistic insurance system, implementing the principle of solidarity of all citizens, or through the enforcement of standards and specific treatment procedures on all healthcare institutions. The state also imposes a number of obligations on individuals, such as undergoing periodic examinations or vaccinations; it can also force treatment on individuals, whose condition threatens others, or even themselves (compulsory treatment of diseases in the initial stages so as to prevent significant deterioration of health, inability to work, etc.), as this brings harm to the community as a whole (Kowalczyk 1996, 108-117; O'Hara 2013; Skrzydlewski 2012, 163-169).

It does not seem that, apart from states with totalitarian or strongly authoritarian regimes and territories, where the state authorities do not function (war zones, failed states), any of the extreme models described here would be implemented. More likely, a golden mean is sought, the essence of which, is to balance the rights and responsibilities of citizens and the state, in such a way, as to ensure the best possible protection of fundamental goods, for example, life and health.

Considering the issue of the limits of the state's actions in the area of healthcare, it should be emphasised, first and foremost, that it should not deprive individuals of their fundamental rights, suppress their freedom, or relieve them of the burden of responsibility for themselves and for others. Instead, it is to assert these rights, and stimulate action for the common good (Galewicz 2014, 68-69). This can be achieved by recognising the dignity of every human being as a fundamental value, incomparable to others, and not interchangeable with others, related to the way in which humans exist as free and rational beings, going beyond the dynamisms of nature and being the subject of rights and duties. The affirmation of the person, i.e., the absolute respect for this value, treating him/her only as an aim, accepting each person and making it possible for him/her to develop fully - to the extent of his/her possibilities - constitute the essential content of the personalistic norm. This principle determines the goal of the community, its common good, which is created, due to the involvement of all its members (Majka 1982, 167-172; Styczeń and Szostek 1974; Szostek 1995, 79-81).

As a result of the recognition of the dignity of the person as the supreme value, state action should be governed by two principles: subsidiarity and solidarity. In accordance with the first principle, the community should not take over tasks, which can be performed by its members on their own initiative, and with their own efforts. The involvement of higher or larger structures should be limited only to those situations where the strength of individuals and small groups is insufficient. Going beyond this principle, excessive interference by larger structures would be a restriction of the freedom of individuals by involving them in various structural dependencies, inhibiting their initiative and their freedom to choose objectives and methods of action. Observance of the principle of subsidiarity reaffirms the servant nature of the community towards its members: the aim of the community is the good of its participants. However, it should be stressed that the richness of life in modern societies means that many activities must be undertaken at the level of broad structures; it would seem that protecting the health and lives of citizens is one such task. It is carried out - to the extent of their possibilities - by local governments, and to some extent, by central authorities (Łuczka 2006, 317; Jurkowska and Owsiak 2010, 117-188; Talone 2008).

The common good, which is the goal of every community, is not created by the mechanistic forces of nature or 
impersonal structures and institutions. It is created by specific individuals, who engage in various activities, and assume responsibility for particular spheres of community life. Thereby, they pursue the principle of solidarity (social love). It is an expression of the responsibility of individuals for the common good, and thus, for one another. Solidarity can be implemented on the level of spontaneous and direct relations between individuals, but also through the functioning of institutions that organisation is regulated at the level of the state. So, using them, the state assigns to citizens certain obligations and imposes restrictions. These may concern both the sphere of prevention, such as limiting access to certain substances, or introducing a vaccination system, and the domain of treatment (compulsory treatment of certain diseases) (Kowalczyk 1996, 256; Kowalewski and Kowalewska 2014, 250-253).

The implementation of the personalistic model, which takes into account the principles of subsidiarity and solidarity, therefore, consists in the fact that each person takes responsibility for his/her own life and health, in accordance with his/her own values and life goals, and is supported by the community, in which he/she lives, both through participation in the system of health insurance and medical services, and through the acquisition of the knowledge needed to make informed choices. At the same time, he/she also takes care to preserve these goods for others. This is expressed in refraining from causing direct harm, protecting against exposure to infection, caring for the environment and working conditions. A sign of solidarity is also the promotion of reliable knowledge about healthcare, and assistance in taking decisions related to prevention and treatment (Garus-Pakowska and Pakowski 2011).

According to the personalistic principle, the state's interference in the citizen's care for himself/herself is very limited. By means of various forms of education, one may shape his/her views and build an attitude of responsibility for oneself and others, and encourage the person to take prophylactic measures, but one cannot force the application of any medical procedure (Schain 1980). Nevertheless, under the conditions of life in a community, where the freedom of one person constitutes a limit on the freedom of others, and where conflicts of interest of particular persons and groups may arise, the state has the right to intervene with the aim of defending the rights of all, especially the weakest, i.e., to create equal living and development conditions for all. The actions of the state should concern, primarily, those situations, in which the health and life of others are directly threatened by the actions or omissions of some. These situations arise, not only in the field of medicine, but also in the regulation of road traffic and fire safety. The state restricts the freedom of all individuals here, in order to ensure the safety of all. At the same time, there may be discussion in the public domain, about which restrictions are necessary, and which are an ineffective burden. This could, for example, be the speed limit for vehicles or the obligation to use seatbelts (seatbelts essentially protect their wearer and not the other road users). In the area of medicine, interference by the state may concern infectious diseases and those situations in the sphere of mental health, where the sick person poses a threat to his/her own safety, and that of others. In the state of a direct threat of spreading the disease or aggression (self-aggression), the first restriction should be isolation of the sick person in conditions safe for him/her and the immediate surroundings. In some systems, the obligation to treat the person is also introduced here, but supporters of a more liberal model of community, emphasise the possibility of the patient - if competent - not consenting to this procedure; it is sufficient to ensure the safety of the environment around the patient. Furthermore, more far-reaching regulations are preventive in nature and concern those at risk of infectious diseases. This refers to forms of epidemiological 
surveillance other than isolation, screening, various sanitary procedures as well as preventive vaccinations. It may also be necessary to deal specifically with the bodies of deceased persons (Garus-Pakowska and Pakowski. 2011; Rogowska 2019, 215).

It is important to emphasise that, as in the case of caring for one's own health and life, a distinction can be made between proportionate and disproportionate, as well as ordinary and extraordinary measures, which may be taken by public institutions, applying the same criteria: medical effectiveness, accessibility, assessment of possible side effects, and compliance with the recognised system of values or religion.

When delineating the limits of the morally acceptable, i.e., not violating the dignity of persons, interference of the state in the sphere of healthcare, one should distinguish between the issue of the individual's care for himself/herself and concern for the health safety of all. However, in the private sphere, the state has little scope for action; the autonomy of the individual does not allow for coercion, but only for the formation of pro-health attitudes through education and various incentives. In the social sphere, the state assumes part of the responsibility for the protection of health and life, and thus, has the right to impose obligations, also under the threat of punishment. However, only those measures, which have the character of proportionate and ordinary measures, both in the area of prevention and therapy, should be regarded as legitimate. Once again, however, it is important, through educational measures, to make citizens aware co-operators who work with public institutions, for the common good.

\subsection{An epidemic - can the state do more?}

There are occasions or longer periods in the life of a community when people's health and lives are at greater risk. These include times of war, natural disasters, failures of water supply or waste disposal systems, and the migration of large groups of people. For various reasons, it is then difficult to observe even the basic rules of hygiene, water and food sources are easily contaminated, sanitary control is difficult, and the functioning of healthcare is disrupted. Under such conditions, certain diseases may spread easily and uncontrollably and cause a much larger number of cases to occur in a given area, than under normal conditions, i.e., an epidemic.

Depending on the level of infectiousness of the disease, its duration, the proportion of cases requiring hospitalisation and the use of specialised equipment, possible complications, and finally, its mortality rate, it depends how serious a threat of an epidemic is to a community. Identifying the extent of this threat, and its nature, is a task for public institutions; and the action taken should be proportionate to the danger identified. However, it must be stressed that the first responsible party here are individuals: people in relationships with others, whose actions directly influence the course of events, above all the spread of the disease.

One might ask whether, in the face of a serious threat, such as an epidemic, the state and its institutions can be vested with special powers. These would involve the possibility of temporarily limiting the freedom of action of citizens, in order to ensure the security of the entire community. The answer depends on the adopted model of relations between the state and its citizens. Supporters of the libertarian model will probably maintain the thesis of minimal state intervention in the lives of citizens. One could speculate that the duty of the relevant institutions would be, above all, to provide information, so that each individual could make rational choices, taking responsibility for himself/herself and his/her environment. It is worth highlighting that in this model, everyone bears the costs of prevention and treatment, either personally, or through private health insurance. Under the collectivist model, the state, by assuming responsibility for the life of the community, acquires the right to far-reaching intervention in the lives of its citizens; due 
to the threat arising, it naturally broadens in a state of epidemic. The more authoritarian the style of government is adopted, the less information citizens can obtain, and the more they are obliged to obey regulations aimed at stopping the spread of the disease and such changes in the organisation of the health service so as to enable it to perform its tasks efficiently.

The state of even a great epidemic threat does not, however, remove the primacy of the dignity of the person as a good which should be the first to be protected, on the part of both individuals and society. Therefore, the requirement of respect for the autonomy of each individual and the obligation of the authorities to create conditions in which he/she can safely and efficiently develop, should be reiterated. Thus, just as under normal conditions, in a state of an epidemic the state plays an auxiliary role, performing those tasks which cannot be performed by individuals or their small associations.

Nor does a state of an epidemic abolish the proportionality of healthcare measures, which is a condition of fairness. No situation justifies the use of treatment or prevention methods that are too risky, ineffective in given conditions, or burdened with excessive adverse effects. The second condition - the ordinariness of measures - is linked to the subjective views and feelings of the patient. In particular, during times of epidemics, the healthcare institutions should do everything possible to ensure that the members of the threatened community accept the various restrictions and undergo the necessary procedures. However, the intervention of the authorities should not be manipulation, but truthful persuasion, linked to the creation of conditions, in which individuals feel safe, on the one hand, and assume personal responsibility for the common good, on the other.

The implementation of these rules is easier, when the nature of the disease is known: the causative agent, the degree of infectiousness, the course, the proportion of severe and life-threatening cases, and the preventive and curative measures that can be taken. This is because in such situations, previously developed procedures are introduced using available and appropriately effective means of prevention and treatment. However, it must be stressed that state institutions can only impose an obligation to observe these procedures, in order to protect the common good. If the sick or endangered person refuses to comply with these procedures, coercive measures (including direct coercion) may only be used to ensure the safety of others.

A special situation is the emergence of a new threat, of a completely unknown nature. Such was the HIV virus identified in 1981 (Barasa 2011), the "swine flu" that emerged in 2009 as a result of mutations of known viruses (Eserink and Cohen 2009), or the severe acute respiratory syndrome caused by the coronavirus SARS-CoV-2, the first cases of which were reported in China, in late 2019. There is, then, no sufficiently confirmed information on the nature of the threat, to provide a basis for action to protect the lives and health of citizens.

It seems that, under these conditions, recognising the responsibility of public institutions for the common good of protecting health, it would be possible to allow tighter restrictions to be imposed on citizens, assuming the existence of a greater (of the possible options) danger, so as to prevent the spread of the disease. Nevertheless, as certain scientific data becomes available, these regulations should be adapted to the facts, immediately. This requires constant and open communication between institutions and the public, an ability to resign from the current, often short-sighted political calculation, to be clear about the objectives of the measures adopted, and to acknowledge that, for various reasons, what is beneficial or even necessary, cannot be done by the authorities.

Another important issue is the possibility of using therapeutic or preventive methods, of not fully proven effectiveness, in a new 
risk situation. Usually, these are not completely new measures, but already known and of proven safety, although of unknown efficacy against the new threat. When introducing them, it is imperative to apply the rules on therapeutic experimentation, especially the principle of informed consent of the patient and the priority of his/ her safety over the possible progress in therapy (Krzyżewska. 2016). The same norms should be applied when searching for new therapeutic or preventive measures; acting under time pressure cannot justify violating the dignity of persons: both those participating in the experimental phase, and those who take medical products, or undergo new procedures immediately after their approval. It is unacceptable for the authorities to use any form of treatment in a coercive manner, and it would also seem necessary to introduce appropriate forms of compensation for those affected by the use of new medicines, vaccines, or treatments.

In conclusion, it should be noted that the essence of an epidemic is a quantitative change, not a qualitative one, compared with the normal state: an increase in the number of cases of disease in a certain area. Therefore, there is no reason to introduce significant changes in the powers of the state towards its citizens. There will be, therefore, above all, an intensification of the activities of public institutions. The possibility of more than usual interference in the lives of citizens should be granted only in exceptional situations, with their consent, and for a limited period of time. A person's dignity should invariably remain the highest good and the object of the most far-reaching protection.

\section{Conclusion}

The care for the protection of life and health is the duty of every human being, for these are basic goods which make it possible to achieve others. In this regard, the individual, on the one hand, needs help and, on the other, is responsible for the health of others. In both aspects, he/she cooperates here with the whole community, represented by, in particular, the state institutions. Of all the possible models of the relationship between the state and the individual, the most appropriate seems to be the personalistic one, in which the dignity of the person, his/her autonomy and development, are the most important goods. The state, in line with the principle of subsidiarity, supports the individual through the organisation of the healthcare system, and defines rules allowing for the solidarity-based protection of the good of each citizen. This model remains exemplary, both in ordinary times, and in times of particular threat to the health and lives of many people, such as during epidemics. The possible restrictions imposed by the state on citizens at such times, also have to be consistent with respect for human dignity and proportionate to the current danger. This is particularly true of the freedom to undertake medical treatment; the state may only use coercion where this relates to the safety of others.

Funding: This research received no external funding.

Board Statement: Not applicable.

Conflicts of Interest: The author declares no conflict of interest.

\section{References}

Barasa, Simon Situma. 2011. "True story about HIV: theory of viral sequestration and reserve infection." HIV/AIDS: Research and Palliative Care 3: 125-133. https://doi.org/10.2147/HIV.S26578.

Bartkowiak, Leszek. 2014. "Czy zdrowie jest dobrem wspólnym?.” Medyczna Wokanda 6.6: 175-183.

Brown, Rebecca C.H. 2013. "Moral responsibility for (un)healthy behaviour." Journal of Medical Ethics 39: 695-698. https://doi.org/10.1136/ medethics-2012-100774

Enserink, Martin and Jon Cohen. 2009. "The Novel H1N1 Influenza." Science 5960: 1607. https://doi. org/10.1126/science.326.5960.1607.

Ferdynus, Marcin. 2021. “O uporczywej terapii oraz środkach zwyczajnych i nadzwyczajnych w polskim kontekście bioetycznym. Na marginesie dwóch debat Polskiego Towarzystwa Bioetycznego." Roczniki Filozoficzne 2: 65-81. 
Galewicz, Włodzimierz. 2014. "Zdrowie jako prawo człowieka." Diametros 42:57-82. https:// doi.org/10.13153/diam.42.2014.682.

Garus-Pakowska, Anna, and Maciej Pakowski. 2011. "Elementy przymusu państwowego w służbie zdrowia publicznego - wybrane zagadnienia." Medycyna Pracy 1: 67-72.

Jurkowska, Aleksandra, and Katarzyna Owsiak. 2010. "Realizacja zasady pomocniczości w warunkach polskich - wybrane przykłady." Zeszyty Naukowe Uniwersytetu Ekonomicznego w Krakowie 840: 107-128.

Juzaszek, Maciej. 2014. "Sprawiedliwość w opiece zdrowotnej z perspektywy różnych koncepcji liberalnego egalitaryzmu." Diametros 42: 106-123 https://doi.org/10.13153/diam.42.2014.684.

Kluz, Marek. 2016. "Troska o dar ludzkiego zdrowia. Odpowiedzialność osobista czy społeczna?” Teologia i Człowiek 1: 47-62.

Kowalczyk, Stanisław. 1996. Człowiek a społeczność. Lublin: Redakcja Wydawnictw KUL.

Kowalewski, Tadeusz, and Jolanta K. Kowalewska. 2014. "Od solidarności do dobra wspólnego koherentność zasad życia społecznego.” Myśl Ekonomiczna i Polityczna 4: 245-255.

Krzyżewska, Barbara. 2016. "Kodeks Norymberski a autonomia jednostki." Studia Ecologiae Et Bioethicae 3: 171-191. https://doi.org/10.21697/ seb.2016.14.3.09

Lewandowski, Roman. 2013. "Perspective of control in the light of professional and managerial role within health care organisations." Przedsiębiorczość i Zarzadzanie 10, part 1: 215-227.

Łuczka, Kinga. 2006. "Zasada pomocniczości jako fundament nowoczesnego państwa." Resovia Sacra 13: 311-321.

Majka, Józef. 1982. Filozofia społeczna. Wrocław: Wydawnictwo Wrocławskiej Księgarni Archidiecezjalnej.

Marton-Gadoś, Katarzyna. 2014. "Dobra wspólnemetodologia badania zjawiska." Myśl Ekonomiczna i Polityczna 4.47: 40-73.
Nieszporska, Sylwia. 2014. "Polityka państwa a sektor ochrony zdrowia w Polsce." Ekonomiczne Problemy Ustug 113: 81-91.

O'Hara, Glen. 2013. “The Complexities of 'Consumerism': Choice, Collectivism and Participation within Britain's National Health Service, c.1961-c.1979." Social History of Medicine 2: 288-304. https://doi.org/10.1093/shm/hks062

Rogowska, Klaudia. 2019. "Ochrona zdrowia jako strategiczny obszar zarządzania państwa." Nierówności Społeczne a Wzrost Gospodarczy 3: 212-225.

Schain, Wendy S. 1980. "Patients' rights in decisionmaking: the case for personalism versus paternalism in health care." Cancer 46.S4: 1035-1041. https:// doi.org/10.1002/1097-0142(19800815)46:4+<1035: AID-CNCR2820461329>3.0.CO;2-H

Skrzydlewski, Paweł. 2012. "Kolektywizm, indywidualizm a osobowa wizja człowieka." In Spór o osobe w świetle klasycznej koncepcji człowieka, edited by Piotr S. Mazur, 123-176. Kraków: Akademia Ignatianum Wydawnictwo WAM.

Styczeń, Tadeusz, and Andrzej Szostek. 1974. “Uwagi o istocie moralności." Roczniki Filozoficzne 2: 21-33.

Tabaszewski, Robert. 2016. Prawo do zdrowia w systemach ochrony praw człowieka. Lublin: Wydawnictwo KUL.

Talone, Patricia. 2008. Principle of Subsidiarity: Challenges and Opportunities in Today's Health Care Environment. Dostęp: 9.10.2021. https://www. chausa.org/publications/health-care-ethics-usa/ article/spring-2008/principle-of-subsidiaritychallenges-and-opportunities-in-today's-healthcare-environment

Wikler, Daniel. 2002. "Personal and Social Responsibility for Health." Ethics \& International Affairs 2: 47-55. https://doi.org/10.1111/J.1747-7093.2002. TB00396.X.

Wróbel, Józef. 1999. Człowiek i medycyna. Teologicznomoralne podstawy ingerencji medycznych. Kraków: Wydawnictwo Księży Sercanów. 